\title{
Android-Based Carrom Game Comics Integrated with Discovery Learning for Physics Teaching
}

\author{
Mega Septiana Ika Rahayu ${ }^{1, *}$ Heru Kuswanto ${ }^{2,}$ Cokro Yongky Pranowo ${ }^{3}$ \\ ${ }^{1}$ Physics Education, Graduate School Program, Universitas Negeri Yogyakarta, Yogyakarta, Indonesia \\ ${ }^{2}$ Physics Education, Graduate School Program, Universitas Negeri Yogyakarta, Yogyakarta, Indonesia \\ ${ }^{3}$ Information Technology, Graduate School Program, STMIK Akakom Yogyakarta, Yogyakarta, Indonesia \\ *Corresponding author. Email: megaseptiana30@gmail.com
}

\begin{abstract}
This study aims to develop an android-based carrom game comics integrated with discovery learning feasible to use in physics teaching. This study was developed using the 4-D: define, design, develop, and disseminate. The feasibility of the developed comics is evaluated by media experts, material experts, physics teachers, peer reviewers, and students. The data analysis used the descriptive analysis for the feasibility assessment of the comics. The result of the research shows that the developed Android-based carom game comics is feasible to be used in physics teaching, which is in a very good category based on the media experts, material experts, physics teachers, peer reviewers, and students. Android-based carrom game comics that are integrated with the discovery learning syntax can encourage students to be actively involved in learning and a very display can attract the attention of students to read and learn.
\end{abstract}

Keywords: Carrom Game, Android, Comics, Discovery Learning.

\section{INTRODUCTION}

Tecnological developments in the industrial revolution 4.0 era demanded education to implement digital technology in the learning process [1]. Digital technology which is currently developing rapidly is a smartphone. Smartphones have been used in education for learning activities including physics learning. The use of smartphones in learning physics such as android is used as a learning medium that can facilitate students in learning [2]. Learning media that are suitable for current technological developments are android-based comics [3], [2], [4].

Android-based comics can display illustrations on abstract concepts. Android-based comics can be used as an alternative to understanding a learning material such as printed comics [7]. Android-based comics have advantages including being able to display animation on abstract concepts; has features and is mobile; and appearance that is interactive, practical and simple [5] ; and can be used anytime and anywhere [4], [8] so that students will be motivated to always learn [3].

The abstract concept of physics, full of mathematical and complicated equations can be simplified by integrating traditional games in learning material through Android [9], [10]. The concept of physics that integrates with traditional games such as the carrom game has not been used to explain physics material as a whole but is only used as an example. When in fact the carrom game contains many physical concepts such as impulsemomentum material seen in figure 1 .

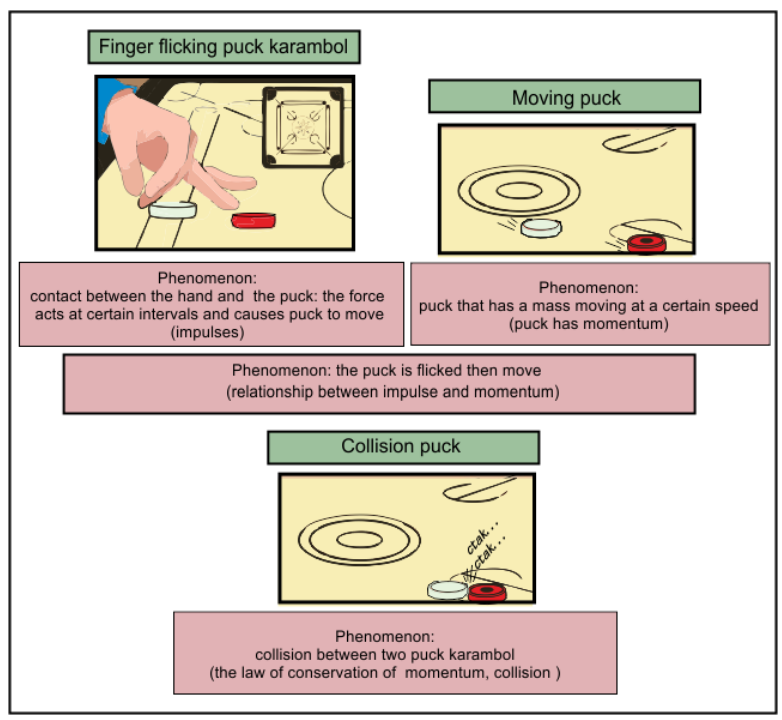

Figure 1. The concept of physics in the carrom game

Android-based comics can also be integrated with approaches and learning models that can help students 
learn actively and independently [11] in accordance with the demands of the 21 st century. One active learning model is the discovery learning model. Discovery learning as an active student learning model. Discovery learning can create effective learning and critical thinking in dealing with a problem in the classroom. [12] so that students' thinking ability can increase [13]. Thus, this research will develop an android-based carrom game comics integrated with discovery learning for physics teaching.

\section{RESEARCH METHOD}

\subsection{Development procedure}

This research belongs to the type of Research and Development (R\&D) with the 4D (Four-D Models) development model by Thiagarajan [14]. The 4D model is divided into several stages namely define, design, develop, and disseminate. The 4-D stages are explained as follows:

a. Define: the stage defines the need for product development.

b. Design: the stage of making carom game comic scenarios containing material momentum and impulses that are integrated with the discovery learning syntax in table 1 and making android media products based on the discovery learning syntax as shown in figure 2.

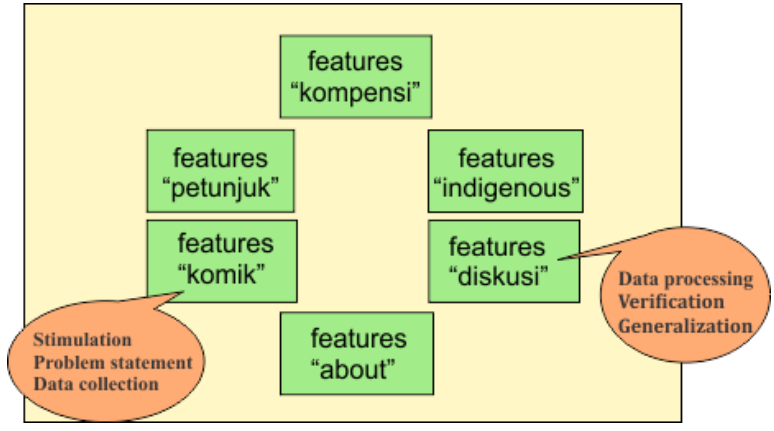

Figure 2. Discovery learning syntax in features of android based comics

c. Development: product development using CorelDRAW X8 and Android Studio. Finished products are evaluated appropriately by material experts, media experts, teachers and peers. Then the students are tested to find out the readability and effectiveness of the product.

d. Disseminate: dissemination is done by uploading to play store, disseminated in international seminars, or publishing articles in indexed journals.

\subsection{Data analysis technique}

The data generated in this study are qualitative and quantitative. Qualitative data in the form of survey needs, suggestions, and comments from experts and students are used to determine the needs of product development and improvement.

Table 1. The syntax of discovery learning in the momentum-impulses

\begin{tabular}{|c|c|c|c|c|c|}
\hline \multirow[b]{2}{*}{$\begin{array}{l}\text { Sintaks } \\
\text { discovery } \\
\text { learning }\end{array}$} & \multicolumn{5}{|c|}{ Material of Impulse and momentum } \\
\hline & Impulse & Momentum & $\begin{array}{l}\text { Reliationship } \\
\text { between } \\
\text { impulse and } \\
\text { momentum }\end{array}$ & $\begin{array}{l}\text { The law of } \\
\text { conservation of } \\
\text { momentum }\end{array}$ & Collision \\
\hline Stimulation & $\begin{array}{l}\text { Presented a } \\
\text { picture of people } \\
\text { flicking the puck } \\
\text { karambol, } \\
\text { students can } \\
\text { analyze the } \\
\text { quantities that } \\
\text { appear when the } \\
\text { puck is flicked }\end{array}$ & $\begin{array}{l}\text { Presented a } \\
\text { picture of puck } \\
\text { karambol that } \\
\text { move toward } \\
\text { the edge of } \\
\text { board and } \\
\text { reflected, } \\
\text { students can } \\
\text { analyze the } \\
\text { quantities that } \\
\text { appear when } \\
\text { the puck moved }\end{array}$ & $\begin{array}{l}\text { Presented a } \\
\text { picture of puck } \\
\text { karambol when } \\
\text { flicked until it } \\
\text { moves, } \\
\text { students can } \\
\text { analyze the } \\
\text { quantities that } \\
\text { appear }\end{array}$ & $\begin{array}{l}\text { Presented a } \\
\text { picture of the } \\
\text { collision between } \\
\text { two pucks of } \\
\text { karambol, } \\
\text { students can } \\
\text { analyze the } \\
\text { velocity and } \\
\text { momentum of } \\
\text { each puck before } \\
\text { and after the puck } \\
\text { collide }\end{array}$ & $\begin{array}{l}\text { Presented a picture } \\
\text { of the collision } \\
\text { between two pucks } \\
\text { of } \\
\text { karambol, students } \\
\text { can } \\
\text { analyze the amount } \\
\text { of kinetic } \\
\text { energy and the level } \\
\text { of resilience material }\end{array}$ \\
\hline $\begin{array}{l}\text { Problem } \\
\text { Statement }\end{array}$ & $\begin{array}{l}\text { Students can } \\
\text { formulate why the } \\
\text { hand hurts when } \\
\text { flicking the puck } \\
\text { quicly }\end{array}$ & $\begin{array}{l}\text { Students } \\
\text { formulate why } \\
\text { pucks that have } \\
\text { same mass can } \\
\text { move at } \\
\text { different }\end{array}$ & $\begin{array}{l}\text { Students can } \\
\text { formulate the } \\
\text { relationship } \\
\text { between } \\
\text { flicking puck } \\
\text { and movement } \\
\text { of puck }\end{array}$ & $\begin{array}{l}\text { Students can } \\
\text { formulate amount } \\
\text { of momentum } \\
\text { before and after } \\
\text { the } \\
\text { Collision) }\end{array}$ & $\begin{array}{l}\text { Students can } \\
\text { formulate the } \\
\text { characteristic of } \\
\text { phenomena that } \\
\text { occur when a puck } \\
\text { collides with the }\end{array}$ \\
\hline
\end{tabular}




\begin{tabular}{|c|c|c|c|c|c|}
\hline \multirow[b]{2}{*}{$\begin{array}{l}\text { Sintaks } \\
\text { discovery } \\
\text { learning }\end{array}$} & \multicolumn{5}{|c|}{ Material of Impulse and momentum } \\
\hline & Impulse & Momentum & $\begin{array}{l}\text { Reliationship } \\
\text { between } \\
\text { impulse and } \\
\text { momentum }\end{array}$ & $\begin{array}{l}\text { The law of } \\
\text { conservation of } \\
\text { momentum }\end{array}$ & Collision \\
\hline & & $\begin{array}{l}\text { velocity and } \\
\text { bounce at } \\
\text { different } \\
\text { velocity as well }\end{array}$ & & & $\begin{array}{l}\text { edge of board or } \\
\text { when it } \\
\text { collides with another } \\
\text { puck }\end{array}$ \\
\hline $\begin{array}{l}\text { (Data } \\
\text { collection, } \\
\text { Data } \\
\text { processing, } \\
\text { Verification) }\end{array}$ & $\begin{array}{l}\text { Students give an } \\
\text { argument about } \\
\text { the } \\
\text { relationship of } \\
\text { the level of hurt } \\
\text { with the concept } \\
\text { of impulse }\end{array}$ & $\begin{array}{l}\text { Students give } \\
\text { an argument } \\
\text { about } \\
\text { relationship } \\
\text { between } \\
\text { velocity and } \\
\text { difficulty in } \\
\text { reducing the } \\
\text { motion of } \\
\text { objects }\end{array}$ & $\begin{array}{l}\text { Students give } \\
\text { an argument } \\
\text { between the } \\
\text { flicking of puck } \\
\text { and the } \\
\text { movement of } \\
\text { puck base on } \\
\text { the concept } \\
\text { relationship } \\
\text { impulse and } \\
\text { momentum }\end{array}$ & $\begin{array}{l}\text { Students give an } \\
\text { argument for } \\
\text { amount of } \\
\text { momentum before } \\
\text { and after the } \\
\text { collision base on } \\
\text { the law of } \\
\text { conservation of } \\
\text { momentum }\end{array}$ & $\begin{array}{l}\text { Students give an } \\
\text { argument about the } \\
\text { characteristic of the } \\
\text { collision of perfect } \\
\text { resilience, partially } \\
\text { resilience, and not } \\
\text { resilience based on } \\
\text { some fact }\end{array}$ \\
\hline $\begin{array}{l}\text { (Generaliza- } \\
\text { tion) }\end{array}$ & $\begin{array}{l}\text { Students can } \\
\text { conclude the } \\
\text { about } \\
\text { concept } \\
\text { impulse }\end{array}$ & $\begin{array}{l}\text { Students can } \\
\text { conclude the } \\
\text { about } \\
\text { concept } \\
\text { momentum }\end{array}$ & $\begin{array}{l}\text { Students can } \\
\text { conclude the } \\
\text { about } \\
\text { concept } \\
\text { relationship } \\
\text { impulse and } \\
\text { momentum }\end{array}$ & $\begin{array}{l}\text { Students can } \\
\text { conclude the } \\
\text { about } \\
\text { concept } \\
\text { the law of } \\
\text { conservation of } \\
\text { momentum }\end{array}$ & $\begin{array}{l}\text { Students can } \\
\text { conclude the about } \\
\text { concept } \\
\text { collision }\end{array}$ \\
\hline
\end{tabular}

While quantitative data in the form of value to determine how much the feasibility of the product produced. Analysis of product feasibility by material experts, media experts, teachers or peers, and students' responses using the average ideal score $(\mathrm{Xi})$ and the ideal standard deviation ( $\mathrm{SBi}$ ):

$X_{i}=\frac{\text { ideal maximum score }+ \text { ideal minimum score }}{2}$

$S B_{i}$

$=\frac{\text { ideal maximum score }- \text { ideal minimum score }}{6}$

Table 2. Convert scores into categories

\begin{tabular}{|c|c|}
\hline Average score range & Quality category \\
\hline$\left(\bar{x}_{i}+3 S B_{i}\right) \geq \mathrm{X} \geq\left(\bar{x}_{i}+1,5 S B_{i}\right)$ & Very good \\
\hline$\left(\bar{x}_{i}+1,5 S B_{i}\right)>\mathrm{X} \geq \bar{x}_{i}$ & good \\
\hline $\bar{x}_{i}>\mathrm{X} \geq\left(\bar{x}_{i}-1,5 S B_{i}\right)$ & Enough \\
\hline$\left(\bar{x}_{i}-1,5 S B_{i}\right)>\mathrm{X} \geq\left(\bar{x}_{i}-3 S B_{i}\right)$ & Not good \\
\hline
\end{tabular}

\section{RESULT AND DISCUSSION}

\subsection{Result of product development}

Comic game based on android carrom integrated discovery learning is shown in figure 3 .
Learning activities begin by guiding students to see videos about the physical phenomenon of the carom game on comic features (stimulation). After seeing the video, students go to the next page by pressing the next button and asking questions related to phenomena in the video by typing the question in the column provided (problem statement). Furthermore, students collect relevant information to answer questions by reading material in the comics from episodes 1-8 (data collection). If students have finished reading then students process data and information from data collection activities by discussing questions on the discussion feature to increase the level of confidence in the information obtained. Then write their answers on a piece of paper (data processing). The answers that have been written are then photographed and uploaded to get a discussion from the application to be matched with the results of the discussion (verification). Verification results are used to conclude by typing conclusions in the column that appears in the discussion (generalization).

Thus, android-based comics can be integrated with learning models or approaches [16]. The syntax of learning models such as discovery learning combined with features on Android that will cause students to be more active and independent in learning activities. Besides, stories in 
comics can also explain theories, procedures, present hypotheses, answer questions, and engage readers to think
[17]. Thus, students will play an active role in the learning process following 21 st-century learning.

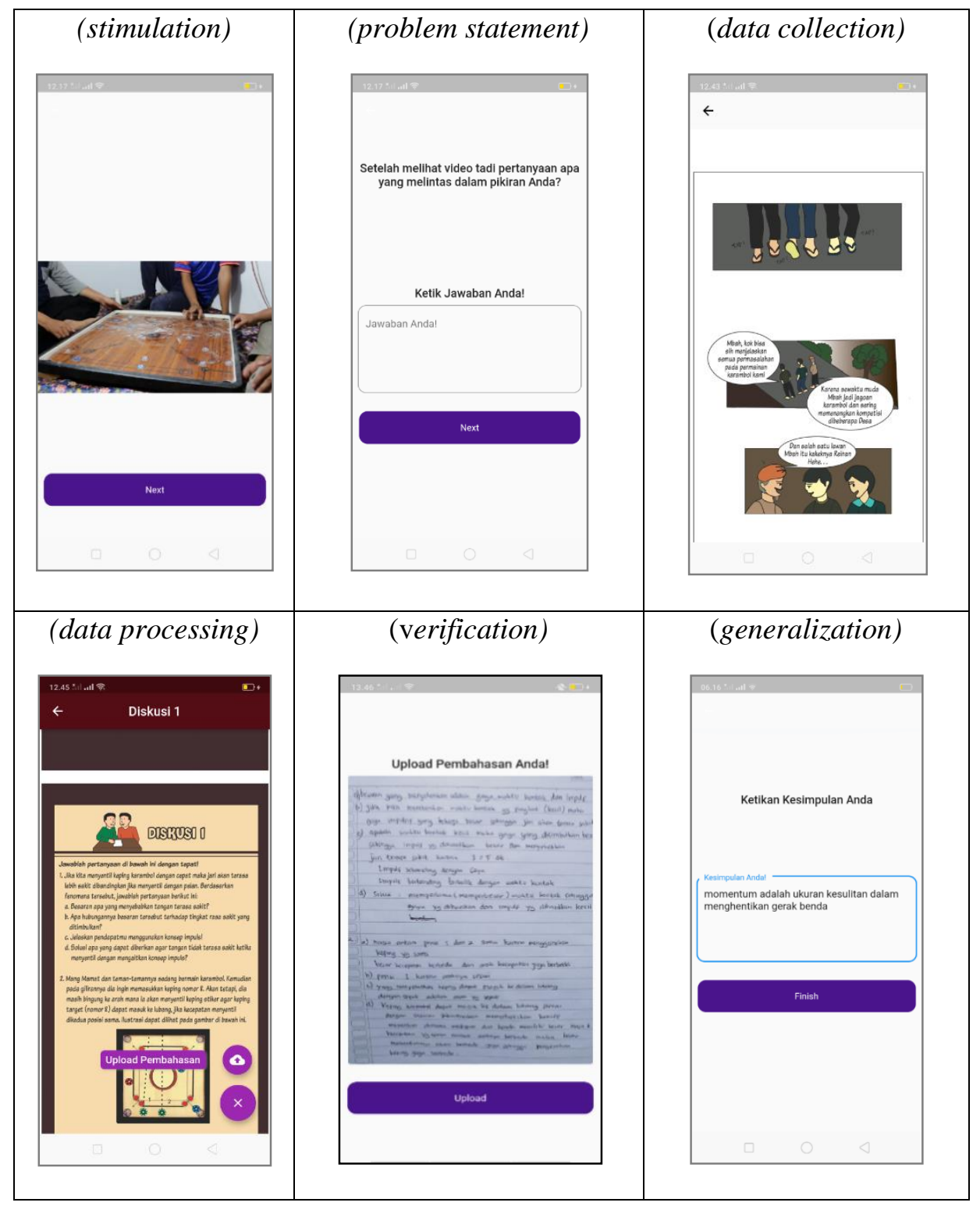

Figure 3. Display android-based comic features that contain the syntax of discovery learning

\subsection{Product feasibility assessment}

The assessment feasible of the Android-based carom comic game-integrated discovery learning by media experts, material experts, physics teachers, and peers can be seen in table 3 .

Table 3. The result of the comic feasibility assessment

\begin{tabular}{|l|l|c|l|}
\hline No & Aspect & Result & Criteria \\
\hline Matter & 3,96 & Very good \\
\hline 1 & Learning & 4,00 & Very good \\
\hline 2 & $\begin{array}{l}\text { Completeness of } \\
\text { contents }\end{array}$ & 3,88 & Very good \\
\hline $3 \quad$ Theory & 3.95 & Very good \\
\hline \multicolumn{3}{|l|}{ Average } \\
\hline Media & 3,92 & Very good \\
\hline 4 & Quality of contents
\end{tabular}

\begin{tabular}{|c|l|c|c|}
\hline 5 & Language & 4,00 & Very good \\
\hline 6 & Implementation & 3,92 & Very good \\
\hline 7 & Design & 4,00 & Very good \\
\hline 8 & Visual display & 3,58 & Very good \\
\hline \multicolumn{2}{|c|}{ Average } & 3,89 & Very good \\
\hline \multicolumn{2}{|c|}{ Average overall } & 3,91 & Very good \\
\hline
\end{tabular}

The highest score is obtained from the aspect of completeness of the content, design, and language. This is because the language presented in comics is simple and easy to understand. Thus, students will more easily understand the information or material delivered using this language [18]. 
Table 4. The results of students' responses to the carom game comic

\begin{tabular}{|l|l|c|c|}
\hline No & Aspect & $\begin{array}{c}\text { Average } \\
\text { response }\end{array}$ & Criteria \\
\hline 1 & Implementation & 3,48 & Very good \\
\hline 2 & $\begin{array}{l}\text { Completeness } \\
\text { of content }\end{array}$ & 3,29 & Very good \\
\hline 3 & Theory & 3,27 & Very good \\
\hline 4 & Design & 3,45 & Very good \\
\hline 5 & Visual display & 3,58 & Very good \\
\hline & Average & 3,41 & Very good \\
\hline
\end{tabular}

Android-based carrom game comics integrated with discovery learning get a very good response from students. The highest response is in the aspect of visual display because the pictures, writing, and videos in the comics can be read clearly on Android. Comics that are visualized using attractive and clear images can facilitate students' understanding of the material presented [19]. The picture will also attract the attention of students to read and learn [20].

\section{CONCLUSION}

Android-based carrom game comics that are integrated with the discovery learning syntax can encourage students to be actively involved in learning and can attract the attention of students to read and learn with very good comic visual display. Thus, the comics developed are suitable for use in physics learning on momentum and impulse material with very good categories based on the assessment of material expert lecturers, media expert lecturers, physics teachers, peer reviewers, and students' responses.

\section{ACKNOWLEDGMENT}

The authors would like to express their sincere gratitude to the Ministry of Research and Technology/National Research and Innovation Agency of Republic Indonesia for funding this research through the Master Thesis Research Scheme (PTM) and the Institute for Research and Community Service (LPPM) which has provided facilities.

\section{REFERENCES}

[1] Iswan, Herwina, Penguatan pendidikan karakter perspektif islam dalam era millenial IR. 4.0, Proceedings Seminar Nasional Pendidikan Era Revolusi, 2018, pp. 21-42.

[2] T.F. Muqarrobin, H. Kuswanto, Open access development of an android-based physics e-book to ease students' physics learning And its influence on their learning achievement, vol. 5, American Journal of Engineering Resesearch (AJER), 2016, pp. 223229.

[3] P.D.A. Putra, M. Iqbal, Implementation of Digital Comic to Improve Creative Thinking Ability in
Integrated Science Study, International Conference on Mathematics and Science Education (ICMScE), 2014. https://doi.org/10.13140/RG.2.1.4299.7286

[4] A.D. Lesmono, R.W. Bachtiar, Maryani, A. Muzdalifah, The instructional-based andro-web comics on work and energy topic for senior high school students, vol. 7, Jurnal Pendidikan IPA Indonesia, 2018, pp. 147-153. https://doi.org/10.15294/jpii.v7i2.14245

[5] W.S. Hadi, P. Dwijananti, Pengembangan komik fisika berbasis android sebagai suplemen pokok bahan radioaktivitas untuk Sekolah Menengah Atas, vol. 4, Unnes Physics Education Journal, 2015, pp. 16-24. https://journal.unnes.ac.id/sju/index.php/upej/article/view/7431

[6] R. Anesia, B.S. Anggoro, I. Gunawan, Pengembangan media komik berbasis android pada pokok bahasan gerak lurus, vol. 1, Indonesian Journal of Science and Mathematics Education, 2018, pp. 53-57.

[7] F. Haroky, S. Nikmah, I. Wilujeng, Jumadi, H. Kuswanto, Android-assisted physics comic learning to train students' conceptual understanding of Newton ' s Gravity, Journal of Physics: Conference Series, $2019 . \quad$ https://doi.org/10.1088/17426596/1233/1/012045

[8] R.H. Ramadhan, I. Wilujeng, H. Kuswanto, Development of student worksheet through deep questions with physics comics to train high order thinking skill in High School Students in optical instrument lup for maximum accommodation eyes, Journal of Physics: Conference Series, 2019, pp. 1-12. https://doi.org/10.1088/1742-6596/1233/1/012057

[9] M. Husna, H Kuswanto, Development of physics mobile learning based on local wisdom to improve vector and diagram representation abilities, vol. 12, International Journal of Interactive Mobile and Technologies, 2018, pp. 85-100. https://doi.org/10.3991/ijim.v12i6.8746

[10] Shabrina, H. Kuswanto, Android-assisted mobile physics learning through Indonesian batik culture: improving students' creative thinking and problem solving, vol 4, International Journal of Intruction, 2018, 287-302. www.e-iji.net

11] N. Fazriyah, Y. Supriyati, W. Rahayu, Watsonglaser's critical thinking skills Watson- Glaser's critical thinking skills, 2nd International Conference on Statistics, Mathematics, Teaching, and Research, 2018, pp. 1-6. https://doi.org/10.1088/17426596/1028/1/012094.

[12] D.R. Permatasari, H. Soegiyanto, B. Usodo, The use of discovery learning model with RME approach 
viewed from interpersonal intelligence, vol. 13, Journal of Education and Learning, 2019, pp. 87-92. https://doi.org/10.11591/edulearn.v13i1.8414

[13] U.E. Sapitri, Y. Kurniawan, E. Sulistri, Penerapan Model Discovery Learning untuk Meningkatkan Keterampilan Berpikir Kritis Siswa Kelas X pada Materi Kalor, vol. 1, Jurnal Ilmu Pendidikan Fisika, 2016, pp. 64-66. https://journal.stkipsingkawang.ac.id/indx.php/JIPF/issue/view/15

[14] D.S. Thiagarajan, M.I. Semmel, Instructional development for training teachers of exceptional children: A sourcebook, Indiana: Indiana University, 1974.

[15] S. Azwar, Tes prestasi: Fungsi dan pengembangan pengukuran prestasi belajar, Yogyakarta: Pustaka Pelajar, 2011.

[16] M.S.I. Rahayu, H, Kuswanto, Development of android-based comics integrated with scientific approach in physics learning, Journal of Physics: Conference Series, 2020, pp. 1-8. https://doi.org/10.1088/1742-6596/1440/1/012040

[17] C.S. Babaian, A.A. Chalian, The thyroidectomy story': comic books, graphic novels, and the novel approach to teaching head and neck surgery through the genre of the comic book, vol. 71, Journal of Surgical Education, 2014, pp. 413-418. https://doi.org/10.1016/j.jsurg.2013.11.008

[18] D.I. Lestari, A.K. Projosantoso, Pengembangan media komik IPA model PBL untuk meningkatkan kemampuan berfikir analitis dan sikap ilmiah, vol. 2, Jurnal Inovasi Pendidikan IPA , 2016, pp. 145-155. https://journal.uny.ac.id/index.php/jipi/article/view/4 529/3901

[19] Irwandani, S. Juariah, Pengembangan media pembelajaran berupa komik fisika berbantuan sosial media instagram sebagai alternatif pembelajaran, vol. 5, Jurnal Ilmiah Pendidikan Fisika Al-Biruni, 2016, pp. 33-42. https://doi.org/10.24042/jpifalbiruni.v5i1.103

[20] E, Albrecht, M.R. Voelzke, Creating comics in physics lessons: An educational practice, vol. 13, Journal of Science Education. 2012, pp. 76-80. https://www.researchgate.net/publication/258670499 